\title{
THE DETERMINANT OF WEBSITE QUALITY AND E-SERVICE QUALITY AT SME IN INDONESIA
}

\author{
Tatik Suryani ${ }^{1 *}$, Abu Amar Fauzi ${ }^{2}$, Moch. Nurhadi ${ }^{3}$ \\ ${ }^{1,2,3}$ Sekolah Tinggi Ilmu Ekonomi Perbanas Surabaya, Indonesia

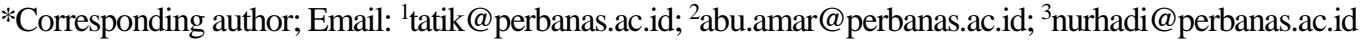

\begin{abstract}
This study aimed to examine the dimensions which determined the website quality and e-service quality in small and medium enterprises (SMEs) in Indonesia. As one of the important determinant dimensions for website quality, e-service quality was specifically observed to find out the specific factors that determined e-service quality which in some previous studies had not been widely studied. The study was conducted by using survey method with questionnaire involving $379 \mathrm{SME}$ customer respondents. Website quality dimensions were measured using a Likert Scale with five alternative answers. The results of the analysis conducted with Smart PLS, showed that there were four dimensions of website quality determinants, of which the most influential were e-service quality, information quality, system quality and image quality; furthermore, for e-service quality dimensions, there were three identified important dimensions including fulfillment, responsiveness, and system availability.
\end{abstract}

Keywords: Website quality, information quality, e-service, system quality.

\section{Introduction}

The trend of utilizing website to support SME business performance in Indonesia is increasing year by year. This is inseparable from the evidence that the website is a marketing communication tool that is useful for promoting goods or services to increase revenue and retain customers (Akincilar \& Dagdeviren, 2014). The website is also able to influence customers in distinguishing a brand (Shin, 2013), so that by simply looking at the customer's website, they can make a purchasing decision. Website quality has important role for determining user behavioural outcome (GarciaMadariaga, Virto, López,_\& Manzano, 2019).

The demand of good website quality is increasing along the number of millennial segments. In Indonesia, total internet users reach 175.4 million in 2020, and 160 million of them actively use social media (Hootsuite, 2020). Data from Global Web Index, stated that Indonesia is the country with the highest rate of ecommerce adoption in the world in 2019 and 90 percent of internet users aged 16 to 64 years have purchased products and services online. This shows that the number of online shoppers is increasing, so the efforts to improve the quality of websites become very strategic to SME.

In the context of marketing, the website is designed to: (1) as a means of communication about the company and the products offered, (2) as a proactive effort to bind (engagement) customers, and (3) a direct selling platform for a company's product (Canavan, Henchion, \& O'Reilly, 2007; Sun, Teh, \& Chiu, 2012). Furthermore, website quality is also important to affect repurchase intention (Wilson, Keni, \& Tan, 2019), customer satisfaction (Rahi, Ghani, \& Ngah, 2020), retain customers and increase customer visits which can ultimately develop e-loyalty from the customers (Akram et al., 2018). Website can also encourage impulsive behavior (Turkyilmaz, Erdem, \& Uslu, 2015) which can increase sales. Hence, great quality website is very important for SME to stand out with their competitors.

Although website quality is seen as important factor, previous studies cited that the dimensions of website quality are evolving and may vary depending on the context. The different dimensions of website quality determinants and the development of customer expectations encourage this research to be carried out, especially regarding the accuracy of information and the quality of SME website in the context of Indonesia.

Thelwall (2000) in a study on SMEs in the UK stated that the quality of a website is determined by: (1) The site's visibility in search engines; (2) ease of use; (3) design quality; and (4) ease of maintenance and updating. Another study in companies whose markets are business markets, website quality is determined by reliability, privacy, efficiency, value-added services, and usefulness of information (Janita \& Miranda, 2013). 
These results differ from studies in hospitality services which reveals that what determines the quality of the website is the ease of use, functionality, security, privacy, and the perceived flow (Ali, 2016). Other research in travel industry found that website quality was determined by ease of use, information, interactivity, and web design (Jiménez-Barreto \& Campo-Martínez, 2018). The finding is different with the website quality determinant in museum services that the dimensions of website quality are content, ease on understanding, emotion, informational-fit-to-task, promotion and visual appeals.

Mostly in previous research, website quality consists of system quality, information quality and e-service quality (Tsao, Hsieh, \& Lin, 2016), but according website developer and customers in Indonesia context, image quality is very important (Suryani, Fauzi, \& Nurhadi, 2019). This result is supported by research in museum services that found one of the dimension of website quality is visual appeal (Garcia-Madariaga et al., 2019). These dimensions are similar with image. To confirm whether image quality is an important dimension in website quality as well as system quality, information quality and e-service quality dimensions in SMEs, this study intends to confirm it as a new dimension based on the developer perspective website and customers are considered as very important (Suryani et $a l ., 2019)$. The results are very important for SMEs practitioners for focusing on important dimensions of website when developing their website.

One of the dimensions of website quality is eservice quality. This research will also examine the determinants of e-service quality, since several previous studies revealed that in different context, the dimensions of e-service is different (Yaya, Marimon, \& Fa, 2012). Research for determining the dimensions of e-service is very important because e-service quality has a positive effect on customer positive responses, such as purchase intention (Rahmawati \& Liswandi, 2018), e-satisfaction and e-loyalty (Kim \& Kim, 2020). In addition, in the context of SMEs there is only a few researches that focuses on the dimensions of e-service, so this research is considered as novel and essentials. By confirming the dimensions of e-service quality in SME, the results can be used for improving e-service quality form customer's perspective and assessing overall of e-service quality.

\section{Website Quality}

It is essential for SME to have a good quality website especially in the field of marketing. This is one of the reasons why studies of the quality of the website in relation to customer response has been carried out in the past few years. Website quality has a significant effect on customer retention (returning customer), customer satisfaction and loyalty (Jeon \& Jeong, 2017), attitude towards the website and lastly the desire of customers to co-create products via online (JiménezBarreto \& Campo-Martínez, 2018). Website quality is seen as playing an important role in differentiating company brands from others (Shin et al, 2013). Other study found that two of dimensions of website quality (system quality and e-service has positive effect on customer satisfaction (Hsu, Chen, \& Kumar, 2018).

In the context of online business development, the study of website quality becomes critical key element of success (Hernandez, Jimenez, \& Martin, 2009). Studies that explore the determinants or dimensions of website quality can be used as a basis for developing quality websites.

An initial study conducted by Thelwall (2000) revealed that website quality can be evaluated based on site visibility on search engines, ease of use, website design quality, and ease of maintenance and updating. Subsequently, another research also evaluated a website by using a multidimensional construct (Loiacono, Watson, \& Goodhue, 2002).

In tourism services, website quality is reflected in the attractiveness of tourist website websites in attracting visitors. There are three important dimensions that determine the effectiveness of a website, namely: usability, quality of information and interactions and service quality (Stockdale, Lin, \& Stoney, 2005). The better usability, quality of information, interaction and service quality, the stronger the desire of consumers to revisit the website. Another study on similar objects shows that the dimensions that determine website quality are the usual aspects, quality of content, information, ease of use and level of interactivity (Loureiro, 2015).

Tsao et al. (2016) based on previous research stated that there are three determinants dimensions of website quality, namely: system quality, information quality and e-service quality. In other study in banking industry, information quality and system quality as the dimensions of website design quality, but online customer service quality as become other construct (Rahi et al., 2020).

The first dimension of website quality is system quality. In e-commerce, system quality is an important element. Customer satisfaction occurs when customers can feel and assess this good system quality. This quality system is formed from technical aspects, functional 
support including software data from the website (Gorla, Somers, \& Wong, 2010). Indicators of this quality system are usability, availability, reliability, adaptability, and response time (DeLone \& McLean, 2004; Hsieh \& Tsao, 2014). Other studies suggest indicators of system quality are ease-to-use website interfaces, speed for downloading, ease navigation for shopping (Tsao et al., 2016). Another research in m-commerce, based on the context, used ease of use, accessibility, interactivity as the indicator of system quality (Mohammad Salameh, \& Abubakar, 2018). Some indicators of the quality system in the context of social shopping are almost the same point despite using different terms namely reliability, search engine functions, and query support functions (Hsu et al., 2018). In this research, based on previously research and preliminary survey in SME, the indicators of system quality are interface, download time, navigation, and reliability of operating function.

The second dimension of web site quality is information quality. Information quality is indicated by: completeness, ease of understanding, timeliness, current, and security (DeLone \& McLean, 2004; Chiu, Chiu, \& Chang, 2007). The quality of information according to Ayyash (2015), the indicators are accuracy, timelessness, completeness, relevancy. Tsao et al. (2016) in their study added one indicator, so indicators of information quality are completeness, understandable, providing the most opportunities for shopping information (richness), current shopping information, and providing secure shopping information. A good website will provide information quality consist of useful, accurate, relevant and objective information (Bao \& Huang, 2018). In this research, considering the context and the indicators in previously research, information quality is indicated by completeness, easily understood, accurate, up to date information, secure information

The third dimension of website quality is e-service. Tsao et al. (2016) in their study used seven indicators of e-service, namely efficiency, system availability, fulfillment, privacy, responsiveness, compensation, and contact. A meta-analysis study of e-service quality states that indicators of e-service quality are aesthetic design, fulfillment, ease of us, personalization, information quality, technical quality, security, customer services (Lionello, Slongo, \& Matos, 2020).

The results of previous studies showed that the determinants of website quality are differ among industries. Mostly most research found that there are three determinants of website quality, namely system quality, information quality, and e-service quality. Hence, based on findings from previous research in SMEs in
Indonesia and also. the results of focus group discussions based on the importance of dimensions of website quality is image (Suryani et al., 2019), so the first hypothesis in this research is:

$H_{I}$ : System quality, information quality, e-service quality, and image quality are the dimensions of website quality.

\section{E-Service Quality (ESQ)}

E-service as a part of website quality is widely researched because it contributes to marketing performance. E-service has a positive effect on customer satisfaction (Rita, Oliveira, \& Farisa, 2019; Ou, Shih, Chen, \& Wang, 2011), increasing customer trust in service providers (Xiu, Benbasat, \& Cenfetelli, 2013; JiménezBarreto \& Campo-Martínez, 2018; Rita et al., 2019). The large role of e-service quality in improving company performance encourages experts to conduct research on the determinant of e-service quality.

An initial study of e-service quality was conducted by Zeithaml, Parasuraman, and Malhotra (2002), which was further developed by Parasuraman, Zeithaml, and Malhotra (2005) who introduced E-S-QUAL. E-SQUAl is a framework consists of scale that could be used to measure the quality of e-service using four dimensions, namely (1) efficiency, (2) compliance, (3) system availability, and (4) privacy. This scale was considered comprehensive at the time, but in its development, in accordance with the development of consumer expectations and the different types of e-services studied, a new dimensions emerged that gave rise to new scale variables and e-service quality.

Loiacono et al. (2002) developed the WebQual scale. There are 12 dimensions of website quality which are then grouped into four sub dimensions, namely (1) usefulness, which consists of information fit-to-task, interactivity, trust, responsiveness; (2) ease of use, this sub-dimension consists of ease of understanding and intuitive operations; (3) entertainment, this subdimension consists of visual appeal, innovation, flow, emotional appeal and (4) complementary relationship, which consists of consistent images, online completeness and better than alternative channels. In the same year, Wu and Ding (2007) in studies in electronic retailing using E-SQ which consists of four dimensions, namely (1) efficiency, (2) system availability, (3) fulfillment, and (4) privacy.

Using the same E-SQ model, several subsequent studies developed different new dimensions. Connolly, Bannister, and Kearney (2010) in their study stated that 
the formers of e-service quality are efficiency, ease of completion, system availability, privacy, and contact. Thus, there are five dimensions that determine e-service quality. On the other hand, Chang (2011) who examined the e-service in pure service companies in Taiwan found that there are seven dimensions of e-service quality determinants, namely efficiency, system availability, fulfillment, privacy, responsiveness, compensation, and contact. The development of the result of determinant of website quality in online shopping also showed that there are seven dimensions of e-service quality determinants, namely efficiency, system availability, fulfillment, privacy, responsiveness, compensation and contact (Tsao et al., 2016; Al-Dweeri, Montes, Obeidat, \& Al-Dwairi, 2019). This dimension also as determinants of e-service in medical service context (Jaiyeoba, Chimbise, \& Roberts-Lombard, 2018).

Research in luxury brand used eight dimensions of e-service quality such as browsing, transaction, company and trust, personalization, product presentation, visual appeal, graphic style and entertainment (Kim \& Kim, 2020). The kinds of dimensions used in the study are adjusted to the empirical conditions of luxury brand products. These results are slightly different from the results of studies on measuring website quality in the tourism sector which found that website quality in tourism is determined by website design, responsiveness, reliability, informative, ease of use, security, empathy, and system availability (Sharma, 2018) This finding support the argumentation that a multi attribute approach provide a conceptual basis for understanding e-service quality (Cobelli, Bonfanti, Cubico, \& Favretto, 2019). These kinds of attribute of the dimensions should be developed based on the characteristic of context.

Based on the previous research, it's found that in different industries impacted the dimensions of e-service quality, and this is influenced by dimensions that are considered important according to the customer in that industries. Specifically, the e-service of industries, is influenced by the level of customer interest. Thus, in this study, based on the multi attribute approach and considering the customer SMEs perspective the second hypothesis is formulated:

$H_{2}$ : Efficiency, system availability, fulfillment, privacy, responsiveness, compensation and contact are the determinants of e-service quality.

\section{Research Methods}

In this study the data collected is cross sectional data, the aim is to examine the dimensions that determine the quality of websites and e-services in SMEs in Indonesia. Data collection is conducted by using survey method with a questionnaire.

The research sample was selected purposively with the quality of SME customers who frequently visited the website and their purchases through the website, and customers who in the past month shopped twice through websites. Questionnaires were distributed to 450 respondents, and 401 complete the respondents. Of the 401 respondents, answers from 23 respondents were not included because the analysis was incomplete. Hence, the respondent in this study was 379 .

The research instruments were arranged in the form of a Likert scale with five alternative answers ranging from 1 (strongly disagree), 2 (disagree), 3 (neutral), 4 (agree), and 5 (strongly agree). Website Quality research instruments are measured based on customer perceptions of website attributes which include system quality, information quality, and electronic service quality (Tsao et al., 2016; Jeon \& Jeong, 2017) and Image quality (Suryani et al., 2019).

E-service quality is measured by customer perceptions of business services through the internet whose indicators are efficiency, system availability, fulfillment, privacy, responsiveness, and compensation and contact (Tsao et al., 2016; Al-Dweeri et al., 2019).

The instrument validity was measured by construct validity with convergent validity and discriminant validity at the 0.05 significance level. Reliability tests are measured by composite and Cronbach Alpha. In addition, the analysis of the dimensions that formed website quality and e-service quality is analyzed using partial least square (PLS) by Smart PLS software. The considerations underlying the use of PLS are the dimensions that form dimensions and determine website quality and eservice quality are formative, not reflective (Garson, 2016).

\section{Results and Discussion}

Before an analysis is conducted, respondents will be described from the study based on demographic characteristics and website usage behavior in shopping on the SMEs.

Referring to Table 1, most respondents were women $(66.49 \%)$, and dominated by $15-20$ years of age (59.37\%) and aged 31-40 years. Mostly, the respondents are high school students, students as well as mothers or young families. This is because most SME products are about fashion, food and food preparations and handicrafts. 
Table 1

Respondent Demography

\begin{tabular}{lcc}
\hline \multicolumn{1}{c}{ Demography } & Frequency & Percentage \\
\hline Gender & 127 & 33.51 \\
Man & 252 & 66.49 \\
Female & & \\
Age & 225 & 59.37 \\
15-20 y/o & 46 & 12.14 \\
$21-30$ y/o & 95 & 25.07 \\
31-40 y/o & 9 & 2.37 \\
41-50 y/o & 4 & 1.06 \\
51 and above & 155 & 40.90 \\
Online shopping frequency through websites on a month \\
1-2 times & 224 & 59.10 \\
More than 2 times & \multicolumn{2}{c}{} \\
\hline
\end{tabular}

Table 2

Convergent Validity Results

\begin{tabular}{|c|c|c|c|}
\hline Dimension & Indicators & $\begin{array}{c}\text { Outer } \\
\text { Loading }\end{array}$ & Result \\
\hline System & Interface & 0.706 & significant \\
\hline Quality & Download time & 0.780 & significant \\
\hline \multirow[t]{3}{*}{ (SQ) } & Navigation & 0.839 & significant \\
\hline & Reliability of & 0.799 & significant \\
\hline & Operating function & & \\
\hline Informa-tion & Completeness & 0.707 & significant \\
\hline Quality & Easily understood & 0.759 & significant \\
\hline \multirow{3}{*}{ (InQ) } & Accurate & 0.817 & significant \\
\hline & $\begin{array}{l}\text { Up to date } \\
\text { information }\end{array}$ & 0.791 & significant \\
\hline & Secure information & 0.733 & significant \\
\hline \multirow[t]{3}{*}{ Image (IQ) } & Image resolution & 0.859 & significant \\
\hline & Clarity & 0.794 & significant \\
\hline & Attractiveness & 0.804 & significant \\
\hline \multicolumn{4}{|c|}{ E-Service Quality (ESQ) } \\
\hline \multicolumn{4}{|c|}{ Contact $(C)$} \\
\hline \multicolumn{2}{|c|}{ WA and SMS availability } & 0.813 & significant \\
\hline \multicolumn{2}{|c|}{ Address availability } & 0.760 & significant \\
\hline \multicolumn{2}{|c|}{ E-service Efficiency $(E F)$} & & significant \\
\hline \multicolumn{2}{|c|}{ Easily to get anywhere on the site } & 0.785 & significant \\
\hline \multicolumn{2}{|c|}{ Easily to find customer needs } & 0.815 & significant \\
\hline \multicolumn{2}{|c|}{ Information is organized well } & 0.769 & significant \\
\hline \multicolumn{4}{|c|}{ Fulfillment $(F)$} \\
\hline \multicolumn{2}{|c|}{ Meet promise } & 0.796 & significant \\
\hline \multicolumn{2}{|c|}{ On time in delivery time } & 0.839 & significant \\
\hline \multicolumn{2}{|c|}{ Accurate promise in delivery } & 0.790 & significant \\
\hline \multicolumn{4}{|c|}{$\operatorname{Privacy}(P)$} \\
\hline \multicolumn{2}{|c|}{$\begin{array}{l}\text { Protect shopping behavior } \\
\text { information }\end{array}$} & 0.768 & significant \\
\hline \multicolumn{2}{|c|}{$\begin{array}{l}\text { Keep personal customer } \\
\text { information }\end{array}$} & 0.806 & significant \\
\hline \multicolumn{2}{|c|}{ Protect credit card information } & 0.806 & significant \\
\hline \multicolumn{4}{|c|}{ Responsiveness $(R)$} \\
\hline \multicolumn{2}{|c|}{ Provide convenience } & 0.775 & significant \\
\hline \multicolumn{2}{|c|}{ Handling product return well } & 0.812 & significant \\
\hline \multicolumn{2}{|c|}{ Response feedback quickly } & 0.809 & significant \\
\hline \multicolumn{4}{|c|}{ Service Recovery (SR) } \\
\hline \multicolumn{2}{|c|}{$\begin{array}{l}\text { Compensation for recovery } \\
\text { service }\end{array}$} & 0.820 & significant \\
\hline \multicolumn{2}{|c|}{ Material compensation } & 0.833 & significant \\
\hline $\begin{array}{c}\text { Guarante } \\
\text { failure }\end{array}$ & f service & 0.830 & significant \\
\hline System Availa & ity $(S A)$ & & \\
\hline Availabilit & for business & 0.789 & significant \\
\hline No crashir & & 0.850 & significant \\
\hline No freezin & & 0.824 & significant \\
\hline
\end{tabular}

According to shopping behavior, most respondents shop through websites. $59.10 \%$ shop more than twice in the past month. This shows that the respondents have a lot of experience in using website to purchase products.

The convergent validity results of the dimensions that determine website quality at a significance level of $5 \%$ are presented in Table 2.

Referring to Table 2, all the dimensions that formed website quality are valid. This is because it has an outer loading factor above 0.7 (Ghozali \& Latan, 2014).

To determine the reliability of this research instrument, an internal consistency reliability test was performed with Cronbach Alpha and composite reliability. The results are shown in Table 3.

Table 3

Cronbach Alpha and Composite Reliability Results

\begin{tabular}{cccl}
\hline Variable & Cronbach Alpha & $\begin{array}{c}\text { Composite } \\
\text { Reliability }\end{array}$ & Results \\
\hline SQ & 0.789 & 0.863 & Reliable \\
In Q & 0.819 & 0.874 & Reliable \\
IQ & 0.757 & 0.769 & Reliable \\
ESQ & 0.905 & 0.908 & Reliable \\
$C$ & 0.677 & 0.823 & Reliable \\
$E F$ & 0.699 & 0.698 & Reliable \\
$F$ & 0.735 & 0.850 & Reliable \\
$P$ & 0.705 & 0.836 & Reliable \\
$R$ & 0.716 & 0.841 & Reliable \\
$S R$ & 0.770 & 0.867 & Reliable \\
$S A$ & 0.758 & 0.861 & Reliable \\
\hline
\end{tabular}

The results of Average Variance Extracted (AVE) analysis showed that for the four dimensions that determine website quality, namely the dimensions of system quality (SQ), information quality (InQ), and the image quality (IQ) values are all values above 0.6, meaning that the three dimensions are unidimensionality. Hence, for each variable on these dimensions, the variables that formed the system quality, information quality, and image have similarities in shaping those dimensions. Whereas the e-service quality showed that the determining sub dimension is not unidimensionality. Thus, the dimension that determines e-service quality difference between one and the other. The influence analysis results of each dimension in determining website quality are presented in Table 4 .

Table 4

The Effect of Dimensions of Website Quality

\begin{tabular}{lcccc}
\hline \multicolumn{1}{c}{ Relationships } & $\begin{array}{c}\text { Original } \\
\text { sample }\end{array}$ & $T$ statistic & $P$ values & Result \\
\hline ESQ --> WQ & 0.630 & 36.561 & 0.000 & significant \\
IQ -- > WQ & 0.123 & 12.982 & 0.000 & significant \\
InQ --> WQ & 0.222 & 21.115 & 0.000 & significant \\
SQ - > WQ & 0.630 & 13.263 & 0.000 & significant \\
\hline
\end{tabular}


Based on Table 4, e-service quality is the dominant dimension in determining website quality with a value of 0.630 , then followed by information quality (InQ) of 0.222 , system quality (SQ) of 0.630 and Image Quality (IQ) of 0.123 . The results of the next analysis, of the dimensions that formed e-service quality are presented in Table 5.

Table 5

Results of E-service Determinant Analysis

\begin{tabular}{lrccl}
\hline Relationships & $\begin{array}{c}\text { Original } \\
\text { sample }\end{array}$ & $\begin{array}{c}T \\
\text { statistic }\end{array}$ & $\begin{array}{c}P \\
\text { values }\end{array}$ & Result \\
\hline C --> ESQ & 0.153 & 10.800 & 0.000 & significant \\
EF --> ESQ & 0.201 & 14.819 & 0.000 & significant \\
F --> ESQ & 0.213 & 18.539 & 0.000 & significant \\
P --> ESQ & 0.194 & 17.360 & 0.000 & significant \\
R -> ESQ & 0.198 & 18.245 & 0.000 & significant \\
SA --> ESQ & 0.215 & 17.860 & 0.000 & significant \\
SR -> ESQ & 0.180 & 14.813 & 0.000 & significant \\
\hline
\end{tabular}

Based on Table 5, the dimensions that shape eservice quality in a row from the largest are fulfillment $(\mathrm{F})$, responsiveness $(\mathrm{R})$, system availability (SA), privacy $(\mathrm{P})$, service efficiency $(\mathrm{EE})$, e-service recovery (SR) and contact (C). The relationship between all variables is presented in Figure 1.

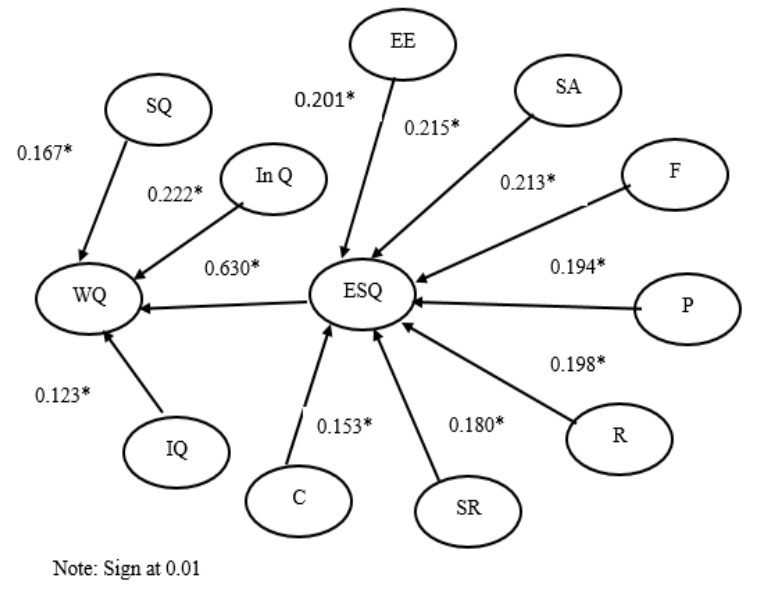

Figure 1. Analysis results

\section{Determinant of Website Quality}

The results showed that there were four dimensions that significantly affect the website quality of SMEs. The four dimensions that determine website quality in an order from the biggest influence are e-service quality, system quality, information quality, and image quality. The results of this study differ from those of Tsao et al. (2016) and Jeon and Jeong (2017) which state that there are three dimensions of website quality, namely eservice quality, system quality, information quality.
There is one additional new dimension, namely the image quality dimension. The addition of the image quality dimension in this research is based on previous research, that SME customers in Indonesia view that image quality is seen as important and affects the quality of the website (Suryani et al., 2019). Web sites that present good images are more attractive to customers.

The results of this study broaden the findings of Rocha (2012) which states that there are three dimensions of website quality, namely content quality, service quality, and technical quality. These three dimensions in this study use terms that are slightly different from it, however it is considered similar dimensions which formed as e-service quality. The new dimension, image quality also confirmed to have a significant influence. These results support the study of Jiménez-Barreto and Campo-Martínez, (2018) which stated that web design is a determining dimension of website quality in tourism services. In relation of previous study with this research, the studies of SMEs with products offered in fashion, handicrafts, and food preparations, the image quality is referred as website design, this means that for corporate websites that offer products, image becomes an important dimension in website quality (JiménezBarreto \& Campo-Martínez, 2018; Wilson et al., 2019).

In addition, related to the previous research, these three dimensions support the results of Tsao et al. (2016) and Jeon and Jeong (2017). Their study revealed that the determinants of website quality are system quality, information quality and e-service. The results of this study also support Hsu et al. (2018) study, which stated that perceived information quality, perceived system quality and perceived service are determinants of website quality.

The indicator of sub dimensions' system quality in this research consistent with studying in online shopping consist of interface, download time, navigation and reliability of operating function (Tsao et al., 2016; Mohammad Salameh et al., 2018) and enrich the indicator of system quality in the prior research the query supporting system, function of search engines and reliability (Hsu et al., 2018).

In this study it was found that information quality is a determinant of website quality. This dimension indicator consists of completeness, easily understood, accurate, updated information and secure information. This indicator wider than the prior research result (Bao \& Huang, 2018).

There is a slight difference in the dimensions of eservice, in the study fewer indicators because it only consists of empathy and reliability. in this study, e- 
service quality is the dominant dimension in determining website quality. From the perspective of customers who make the purchase, e-service is defined as the experienced by them starting from searching for information, making transactions, and getting post-purchase services (if needed), so that good quality e-service is needed. During the search for information customers will look for contacts, even trying to access when there are problems or unclear information. When interacting first with the website the customer will assess the ease of access and ease of finding information (system availability). Website's ability and to fulfill customer needs (fulfillment), website's ability to keep customer data confidential (privacy), speed in responding to customer complaints (responsiveness), and company actions to perform service recovery when customers experience service failure. These attributes are sub dimensions of eservice quality.

\section{Determinant for E-Service Quality}

The results found that e-service quality was determined in succession from the greatest contribution (1) fulfillment, (2) responsiveness, (3) system availability, (4) privacy, (5) e-service efficiency, (6) e-service recovery, and (7) contact. This study is new because there has not been a study of e-services on the small and medium enterprises' website. The dimension that forms e-service quality is not unidimensional, it is indicated from the Average Variance Extracted (AVE) value of 0.348 . The dimensions found in this study partially support the results of previous studies. Different industrial contexts cause different dimensions that determine e-service. In studies in the banking industry the dimensions of e-service consist of reliability, responsiveness, competences, service availability, privacy service portfolio (Ayo, Oni, Adewoye, \& Eweoya, 2016). In the pure service industry, e service dimensions are determined by seven dimensions, namely (1) efficiency, (2) system availability, (3) fulfillment, (4), privacy, (5) responsiveness (6) compensation, (7) and contact (Chang, 2011). If related to Chang's research, it is actually substantially the same relative, there is only one naming of different dimensions. The dimensions of compensation, in this study, some of the indicators are included in the service recovery dimension. research where SME customers attach importance to compensation and ultimately service recovery if a customer experiences a service failure while searching for information, repurchasing and purchasing. This result is consistent with the study conducted by Tsao et al. (2016) on online shopping and also in medical service (Jaiyeoba et al., 2018) which show that there are seven dimension that could determine e-service, those dimensions that determine e-service quality are (1) fulfillment, (2) responsiveness, (3) system availability, (4) privacy, (5) eservice efficiency, (6) e-service recovery, and (7) contact.

Furthermore, this research also shows the role of each dimension in explaining e-service. This research found that the biggest dimension contributor for eservice is Fulfillment. This dimension is an indicator of the company's ability to meet customer needs, product supply and promises delivered to customers. For customers, the certainty of these three things is important, therefore the biggest contribution in determining the quality of service. This finding consistent with the prior research which found that fulfillment as the determinant of e-service quality (Tsao et al., 2016; Jaiyeoba et al., 2018). The difference is in the amount of contribution in determining e-service quality, where in the Tsao et al. (2016) study the largest contribution is e-service efficiency.

The second dimensions that could determine eservice quality is responsiveness. The speed when responding actions taken by the customer are highly expected by the customer, so that when the company is slow in responding to customer problems and difficulties, the customer considers that the company's e-service is bad. This result is different from the study of Tsao et al. (2016) who rank responsiveness as the first dimension in determining e-service quality. Paying attention to the results of this study and referring to the results of previous studies, this study concludes that that responsiveness is very important to consider in e-service for online product sales.

The third dimension that determines e-service quality is system availability. System availability is the ability to provide systems that could be accessed easily, smoothly and requires less time when customers make transactions. This finding consistent with research in career guidance e-services (Cobelli et al., 2019). When compared to the magnitude of the contribution of this dimension in determining e-service quality is different from other findings. The position of this dimension in medical services is in the fifth rank (Jaiyeoba et al., 2018) and at on online shopping (Tsao et al., 2016) it is the lowest determinant of contribution. This result shows that in different industrial contexts although these dimensions significantly determine e-service quality, but the contribution might vary depending on the industries. 
The fourth dimension that determines e-service quality is privacy. For data security, customers' data are considered as an important part of online services, therefore privacy is a significant dimension in determining e-service quality. Several previous studies on different industries regarding the determinants of eservice quality also showed that privacy impact the eservice quality of a website. (Chang, 2011; Connolly et al. (2010); Tsao et al. (2016); Wu \& Ding, 2007; Hsu et al., 2018; Lionello et al., 2020).

The fifth dimension that makes up e-service quality is e-service efficiency. E-service efficiency is the ease of access, the ease of getting things needed, and the ease of getting information. For SME customers this convenience is important when searching for products and information on purchases. Efficiency in several studies is also seen as an important dimension in e-service quality in the context of pure services (Chang, 2011) and public service agencies Connolly et al. (2010) and Cobelli et al. (2019).

The sixth dimensions that determine e-service quality are e-service recovery which is carried out online. E-service recovery is defined as the efforts of SMEs in fixing a service so that dissatisfied customer can become satisfied. Service failures could be depicted as a company's inability to fulfill product or as stated on the website, failure to deliver products on time, and product incompatibility with the information presented. This finding is consistent with the previous study of Tsao et al. (2016) and is a determining factor for e-service quality.

The seventh dimension of e-service quality is contact. On most websites the contact is displayed on the SMEs website. The contact in a website typically appear in the form of telephone number, email address or social media address. Although its contribution in determining e-service quality is not significant, it is still seen as important as a means of accessing the company. These results are consistent with previous research that found contact as a dimension of e-service (Chang, 2011; Tsao et al., 2016).

\section{Conclusion and Implication}

This research has presented its finding on determinants of website quality and e-service quality in the context of SMEs, which can complement other studies with the same topic, but in different industries. Furthermore, the results of this study are very suitable to be considered by SMEs in designing websites and designing e-services.
This research also adds a new dimension, which is image. This dimension originally was raised as a dimension based on the results of previous studies. This finding provides important implications in the development of theory, specifically the construct of website quality. Previous studies of website quality mostly consisted of three dimensions, whereas in this study the results showed that determinant website quality in SMEs consisted of four dimensions. This shows the importance of the image on the website according to the customer. Customers rate the quality of the image as a determinant of the quality of the website.

The managerial implication in business is when designing a website, SMEs need to be creative and attractive on creating images that are clear, good and unique so that customers are interested in visiting the website, which will indirectly influence customers to buy their products.

In addition, the results of this study indicate that the determinants of website quality in SMEs from those most contributing to determining website quality are eservice quality, followed by information quality, system quality and image. The existence of a new dimension of image that is seen as important for SME customers, has implications for the importance of the SME website developers to not only pay attention to e-service, system quality, and Information quality but also on how the website in terms of images are designed to be interesting and attractive when visited.

The discovery of e-service as a dominant dimension in determining website quality has an important implication for SMEs to have clear procedures and standards in the development of the website and its supporting management operational system in order to meet customer needs (fulfillment), responsiveness, ensuring that the availability system runs well, maintaining customer data confidential (privacy), e-service efficiency, e-service recovery, and making sure there are contacts on the website and can be contacted. The company should establish procedures and standards and comply with these provisions in the process of providing services to customers. To ensure this is done, it is necessary to evaluate based on customer feedback so that the e-service can be maintained quality.

Lastly, the results of this research could enhance the website quality and e-service quality constructs that in previous years were developed in different industries. the dimensions of website quality and e-service need to be further examined to predict the attitudes and behavioral responses of consumers such as brand image, brand identification, satisfaction, and purchase 
intentions. For future research direction, this study suggested that the website and service quality need to be observed based on specific to certain types of businesses such as food processing, fashion, or agribusiness. Hence, the selection of SMEs should be done specifically according to their business industries and its objectives.

\section{Acknowledgement}

Thank to The Ministry of Education and Culture of the Republic of Indonesia for the Grants for conducting this research.

\section{References}

Akincilar, A., \& Dagdeviren, M. (2014). A hybrid multicriteria decision-making model to evaluate hotel websites. International Journal of Hospitality Management, 36, 263-271. https://doi.org/10. 1016/j.j.jhm.2013.10.002

Akram, U., Hui, P., Khan, M. K., Tanveer, Y., Mehmood, K., \& Ahmad, W. (2018). How website quality affects online impulse buying: Moderating effects of sales promotion and credit card use, Asia Pacific Journal of Marketing and Logistics, 30(1), 235-256. https://doi.org/10.1108/APJML-042017- 0073

Al-Dweeri, R. M., Ruiz Moreno, A., Montes, F. J. L., Obeidat, Z. M., \& Al-Dwairi, K. M. (2019). The effect of e-service quality on Jordanian student's eloyalty: An empirical study in online retailing. Industrial Management \& Data Systems, 119(4), 902-923. https://doi.org/10.1108/IMDS-12-20170598

Ali, F. (2016). Hotel website quality, perceived flow, customer satisfaction and purchase intention. Journal of Hospitality and Tourism Technology, $7(2), 213-228$.

Ayo, C. K., Oni, A. A., Adewoye, O. J., \& Eweoya, I. O. (2016). E-banking users' behaviour: E-service quality, attitude, and customer satisfaction. International Journal of Bank Marketing, 34(3), 347367.

Ayyash, M. M. (2015). Identifying information quality dimensions that affect customers satisfaction of ebanking services. Journal of Theoretical and Applied Information Technology, 82(1), 122-130.

Bao, Z., \& Huang, T. (2018). Exploring stickiness intention of $\mathrm{B} 2 \mathrm{C}$ online shopping malls: A perspective from information quality, International Journal of Web Information System, 14(2), 1-22. https://doi.org/10.110 8/IJWIS-10-2017-0071.
Canavan, O., Henchion, M., \& O’Reilly, S. (2007). The use of the internet as a marketing channel for Irish specialty food. International Journal of Retail \& Distribution Management, 35(2), 178-195. https:// doi.org/10.1108/09590550710728110

Chang, W.-L. (2011). A mixed-initiative model for quality-based e-services pricing. Total Quality Management \& Business Excellence, 22(9), 975991. https://doi.org/10.1080/14783363.2011.593 853

Chiu, C. M., Chiu, C. S., \& Chang, H. C. (2007). Examining the integrated influence of fairness and quality on learners' satisfaction and web-based learning continuance intention. Information Systems Journal, 17(3), 271-287. https://doi.org/10. 1111/j.1365-25 75.2007.00238.x

Cobelli, N., Bonfanti, A., Cubico, S., \& Favretto, G. (2019). Quality and perceived value in career guidance e-services. International Journal of Quality and Service Sciences, 11(1), 53-68. https://doi.org/10.1108/IJQS S-12-2017-0114

Connolly, R., Bannister, F., \& Kearney, A. (2010). Government website service quality: A study of the Irish revenue online service. European Journal of Information Systems, 19, 649-667. DOI: 10.1057/ ejis. 2010.45

DeLone, W. H., \& McLean, E. R. (2004). Measuring ecommerce success: Applying the DeLone \& McLean information systems success model. Information Journal of Electronic Commerce, 9(1), 31-47.

Garcia-Madariaga, J., Virto, N. R., López, M. F. B., \& Manzano, J. A. (2019). Optimizing website quaity: The case of two superstar museum websites. International Journal of Culture, Tourism and Hospitality Research, 13(1), 16-36.

Garson, G. D. (2016). Partial least squares: Regression \& structural equation models. Asheboro, NC: Statistical Associates Publishers.

Ghozali, I., \& Latan, H. (2014). Partial least squares: Konsep, teknik dan aplikasi menggunakan program Smart PLS3.O. Edisi Kedua. Semarang: Universitas Diponegoro.

Gorla, N., Somers, T. M., \& Wong, B. (2010). Organizational impact of system quality information quality and service quality. The Journal of Strategic Information Systems, 19, 207-228. doi:10.1016/j.jsis.2010.05. 001

Hernandez, B., Jimenez, J., \& Martin, M. J. (2009). Key website factors in e-business strategy. International Journal of Information Management, 29, 362-371. doi:10.101 6/j.jinfomgt.2008.12.006. 
Hootsuite. (2020). Hootsuite (we are social): Indonesian digital report 2020. Retrieved from https://andi. link/hootsuite-we-are-socia 1-indonesian-digitalreport-2020/

Hsieh, M. T., \& Tsao, W. C. (2014). Reducing perceived online shopping risk to enhance loyalty: A website quality perspective. Journal of Risk Research, 17(2), 241-261. https://doi.org/10.1080/1366 9877.2013.794152

Hsu, C., Chen, M., \& Kumar, V. (2018). How social shopping retains customers? Capturing the essence of website quality and relationship quality. Total Quality Management, 29(2), 161-184.

Jaiyeoba, O. O., Chimbise, T. T., \& Roberts-Lombard, M. (2018). E-service usage and satisfaction in Botswana. African Journal of Economic and Management Studies, 9(1), 2-13.

Janita, M. S., \& Miranda, F. J. (2013). Exploring service quality dimensions in B2B e-marketplaces. Journal of Electronic Commerce Research, 14(4), 363386.

Jeon, M. M., \& Jeong, M. (2017). Customers' perceived website service quality and its effects on e-loyalty. International Journal of Contemporary Hospitality Management, 29(1), 438-457. https://doi.org/ 10.1108/IJ CHM-02-2015-0054

Jiménez-Barreto, J., \& Campo-Martínez, S. (20 18). Destination website quality, users' attitudes and the willingness to participate in online co-creation experiences. European Journal of Management and Business Economics, 27(1), 26-41. https://doi. org/10.1 108/EJMBE-11-2017-0048

Kim, J. H., \& Kim, M. (2020). Conceptualization and assessment of e-service quality for luxury brands. The Service Industries Journal, 40(5-6), 436-470. https://doi.org/10.1 080/02642069.2018.1517755

Lionello, R. L., Slongo, L. A., \& Matos, C. A. D. (2020). Marketing Intelligence \& Planning, 38(5), 619635.

Loiacono, E. T., Watson, R. T., \& Goodhue, D. L. (2002). Webqual: A measure of website quality. Marketing Theory and Applications, 13(3), 423438.

Loureiro, S. M. C. (2015). The role of website quality on $\mathrm{PAD}$, attitude and intentions to visit and recommend island destination. International Journal of Tourism Research, 17(6), 545-554. https://doi.org/ 10. $1002 /$ jtr. 2022

Mohammad Salameh, A. A., Ahmad, H., Zulhumadi, F., \& Abubakar, F. M. (2018). Relationships between system quality, service quality, and customer satisfaction: M-commerce in the Jordanian context, Journal of Systems and Information Technology, 20 (1), 73-102. https://doi.org/10.1108/JSIT-032017-0016

Ou, W. M., Shih, C. M., Chen, C. Y., \& Wang, K. C. (2011). Relationships among customer loyalty programs, service quality, relationship quality and loyalty: An empirical study. Chinese Management Studies, 5(2), 194 -206. https://doi.org/10.1108/ 17506141111142825

Parasuraman, A., Zeithaml, V., \& Malhotra, A. (2005). E-S-QUAL: A multiple-item scale for assessing electronic service quality. Journal of Service Research, 7(3), 213-233

Rahi, S., Ghani, M. A., \& Ngah, A. H. (2020). Factors propelling the adoption of internet banking: The role of e-customer service, website design, brand image and customer satisfaction. Int. J. Business Information System, 33(4), 549-569.

Rahmawati, Y., \& Liswandi. (2018). Analysis of eservice quality dimensions towards purchase intention by using smartphone in Tokopedia. International Journal of Management, Accounting and Economics, 5(4), 260 -271.

Rita, P., Oliveira, T., \& Farisa, A. (2019). The impact of e-service quality and customer satisfaction on customer behavior in online shopping. Heliyon, 5, 114. https://doi.org/10.1016/j.heliyon.2019.e02690

Rocha, A. (2012). Framework for a global quality evaluation of a website. Online Information Review, 36(3), 374-382. https://doi.org/10. 1108/146 84521211241404

Sharma, N. (2018). Developing and validating an instrument for measuring online service quality in the tourism sector. The IUP Journal of Management Research, 17(1), 38-70.

Shin, J. I., Chung, K. H., Oh, J. S., \& Lee, C. W. (2013). The effect of site quality on repurchase intention in internet shopping through mediating variables: The case of university students in South Korea, International Journal of Information Management, 33 (3), 453-463. https://doi.org/10.1016/j.ijinfomgt. 2013.02 .003

Stockdale, R., Lin, C., \& Stoney, S. (2005). The effectiveness of SME websites in a business to business context. Proceeding of IADIS International Conference e-commerce, 259 -266. Portugal, IADIS Press.

Sun, H., Teh, P.-L., \& Chiu, A. (2012). An empirical study on the websites service quality of Hong Kong 
small businesses. Total Quality Management \& Business Excellence, 23 (7/8), 931-947. https://doi. org/10.1080/ 14783363.2012 .704273$.

Suryani, T., Fauzi, A. A., \& Nurhadi, M. (2019). Determinan kualitas website pada perusahaan skala kecil dan menengah. Proceeding Seminar Nasional Ilmu Terapan (SNITER) 2019, Universitas Widya Kartika, E1-8. https://ojs.widyakartika.ac.id/index.php/sniter/article/view/108/104

Thelwall, M. (2000). Effective websites for small and medium-sized enterprises. Journal of Small Business and Enterprise Development, 7(2), 149-159. https://doi.org/10.11 08/EUM0000000006836.

Tsao, W. C., Hsieh, M. T., \& Lin, T. M. Y. (2016). Intensifying online loyalty! The power of website quality and the perceived value of consumer/seller relationship. Industrial Management \& Data Systems, 116(9), 1987-2010. https://doi.org/10.1108/IMDS-07-20 15-0293.

Turkyilmaz, C. A., Erdem, S., \& Uslu, A. (2015). The effects of personality traits and website quality on online impulse buying. Procedia -Social and Behavioral Sciences, 175, 98-105. doi: 10.1016/ j.sbspro.2015.01.1179.
Wilson, N., Keni, K., \& Tan, P. H. P. (2019). The effect of website design quality and service quality on repurchase intention in the e-commerce industry: A cross-continental analysis. Gadjah Mada International Journal of Business, 21(2), 187-222. https://doi. org/10.22146/gamaijb.33665.

Wu, K.-W., \& Ding, M.-C. (2007). Validating the American customer satisfaction index model in the online context: An empirical study of U.S. consumer electronics e-tailers. International Journal of Business and Information, 2(2), 199-220.

Xiu, J., Benbasat, I., \& R.T. Cenfetelli. (2013). Integrating service quality with system and information quality: An empirical test in the e-service context, MIS Quarterly, 37(3), 777-794.

Yaya, L. H. P., Marimon, F., \& Fa, M. C. (2012). Assessing e-service quality: The current state of ES-QUAL. Total Quality Management \& Business Excellence, 23 (11-12), 1363-1378. https://doi.org/ 10.1080/14783 363.2012.728850.

Zeithaml, V. A., Parasuraman, A., \& Malhotra, A. (2002). Service quality delivery through web sites: A critical review of extant knowledge. Journal of the Academy of Marketing Science, 30(4), 362375. DOI: 10.1177/00 9207002236911. 